DOI:10.15740/HAS/IJAS/17.2/630-635

\title{
Effect of Azotobactor and Pseudomonas along with various levels of NPK on growth and flowering of marigold cv. Pusa Narangi Gainda
}

\author{
Shabnam Kumari*, Kulveer Singh Yadav, Harmandeep Kaur and Sachin Kishor \\ School of Agricultural Sciences and Technology, RIMT University, Mandi Gobindgarh (Punjab) India \\ (Email:namshab43@gmail.com)
}

\begin{abstract}
The experiment was carried at Agriculture Farm, School of Agricultural Sciences and Technology, RIMT University, Mandi Gobindgarh, Punjab, India. This investigation was done to study the effect of different biofertilizers and NPK level on vegetative growth and flowering parameters of marigold cv. Pusa Narangi Gainda during 2019-20. Experiment was laid out in a Randomized Block Design with three replications. Results revealed that, number of leaves/plant (303.98), fresh weight of leaf (4.34 $\mathrm{g})$, dry weight of leaf $(1,68 \mathrm{~g})$, leaf biomass/plant $(1103.03 \mathrm{~g})$ and stem diameter $(1.54 \mathrm{~cm})$ were resulted when plants of marigold treated with treatment $\mathrm{T}_{10}\left(75 \% \mathrm{NPK}+\mathrm{N}_{2}\right.$ fixer (Azotobactor) $+\mathrm{PSB}$ (Pseudomonas) + RDFYM). In concern with flowering parameters, the results revealed that the number of flowers/plant (36.07), fresh weight of flower $(6.89 \mathrm{~g})$ and longer flower longevity (34.61 days) were resulted by under $\mathrm{T}_{10}\left(75 \% \mathrm{NPK}+\mathrm{N}_{2}\right.$ fixer (Azotobactor) + PSB (Pseudomonas) $\left.+\mathrm{RDFYM}\right)$ not with standing, more dry weight of flower (1.91 g) and longer duration of flowering (49.51 days) were recorded under the treatment $\mathrm{T}_{9}$ i.e. $75 \%$ NPK + PSB (Pseudomonas).
\end{abstract}

Key Words : Marigold, Biofertilizers, PSB, Azotobactor, Pusa Narangi Gainda

View Point Article : Kumari, Shabnam, Yadav, Kulveer Singh, Kaur, Harmandeep and Kishor, Sachin (2021). Effect of Azotobactor and Pseudomonas along with various levels of NPK on growth and flowering of marigold cv. Pusa Narangi Gainda. Internat. J. agric. Sci., 17 (2) : 630-635, DOI:10.15740/HAS/IJAS/17.2/630-635. Copyright@ 2021: Hind Agri-Horticultural Society.

Article History : Received : 26.03.2021; Revised : 11.04.2021; Accepted : 21.04.2021

\footnotetext{
* Author for correspondence :
} 